\title{
GeRmination of SEVEN SPECIES OF SHRUBS IN SEMIARID CENTRAL MEXICO: EFFECT OF DROUGHT AND SEED SIZE
}

\section{GeRminACIÓN DE SIETE ESPECIES DE ARBUStOS EN EL CENTRO SEMIÁRIDO DE MÉXICO: EFECTO DE LA SEQUÍA Y EL TAMAÑO DE LA SEMILLA}

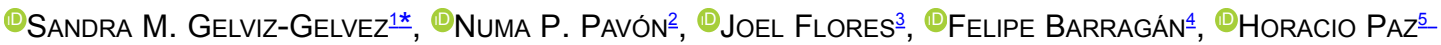 \\ ${ }^{1}$ Instituto de Investigación de Zonas Desérticas, Universidad Autónoma de San Luis Potosí, México. \\ ${ }^{2}$ Centro de Investigaciones Biológicas, Universidad Autónoma del Estado de Hidalgo, Ciudad del conocimiento. México. \\ ${ }^{3}$ División de Ciencias Ambientales, IPICYT, San Luis Potosí, México. \\ ${ }^{4}$ CONACYT-IPICYT División de Ciencias Ambientales, San Luis Potosí, México. \\ ${ }^{5}$ Instituto de Investigaciones en Ecosistemas y Sustentabilidad, Universidad Nacional Autónoma de México, Morelia, Michoacán, \\ México. \\ *Corresponding author: sandra.gelviz@uaslp.mx
}

\begin{abstract}
Background: In semiarid ecosystems, many plant species are tolerant to drought. However, increased aridity as a result of climatic change could modify the capacity of germination and establishment.

Hypothesis: Under drought conditions, small-seeded species will tend to germinate in higher proportions than large-seeded species because the former have larger surface-to-volume ratio, allowing for more rapid water uptake.

Study species: Ageratina espinosarum, Flourensia resinosa, Montanoa tomentosa and Gymnosperma glutinosum (Asteraceae), Dalea bicolor, Eysenhardtia polystachya and Mimosa pringlei (Fabacecae).

Study site: Hidalgo, Mexico. September 2015.

Methods: We evaluated the effect of five water potential treatments on seed germination. Four dishes (replicates), each with 25 seeds, were used in each treatment. Seeds of each species were weighed and the relationship between seed germination under water stress and seed size was obtained.

Results: Germination decreased as water potential was reduced; almost no seeds germinated at $-0.8 \mathrm{MPa}$. The least sensitive species was Eysenhardtia polystachya, whose germination reached $35 \%$ at $-0.6 \mathrm{MPa}$. A positive relationship was found between seed size and germination proportion under water stress.

Conclusions: Contrary to expectation, germination was higher in the large-seeded species in all drought treatments, suggesting that large seeds may have a greater capacity to retain water in dry environments.
\end{abstract}

Keywords: Polyethylene glycol, seeds, semiarid zone, water stress.

\section{Resumen}

Antecedentes: En ecosistemas semiáridos muchas especies de plantas son tolerantes a la sequía. Sin embargo, el aumento de la aridez como resultado del cambio climático podría modificar la capacidad de germinación y establecimiento.

Hipótesis: En condiciones de sequía, las especies de semillas pequeñas tenderán a germinar en mayores proporciones que las especies de semillas grandes debido a que las primeras tienen una mayor relación superficie volumen, permitiendo la absorción de agua más rápida.

Especies de estudio: Ageratina espinosarum, Flourensia resinosa, Montanoa tomentosa and Gymnosperma glutinosum (Asteraceae), Dalea bicolor, Eysenhardtia polystachya y Mimosa pringlei (Fabacecae).

Sitio de estudio: Hidalgo, México. Septiembre 2015.

Métodos: Se evaluó el efecto de cinco tratamientos de potencial hídrico en la germinación. Se usaron cuatro cajas Petri (replicas) por tratamiento con 25 semillas por repetición. Las semillas de cada especie fueron pesadas y se obtuvo la relación entre germinación de semillas bajo estrés hídrico y tamaño de semillas.

Resultados: La germinación disminuyó a medida que se redujo el potencial hídrico; casi ninguna semilla germinó a -0.8 MPa. La especie menos sensible fue Eysenhardtia polystachya, cuya germinación alcanzó el 35 \% a -0.6 MPa. Bajo estrés hídrico, se encontró una relación positiva entre el tamaño de la semilla y la proporción de germinación.

Conclusiones: Contrario a lo esperado, la germinación fue mayor en las especies de semillas grandes en todos los tratamientos de sequía, lo que sugiere que las semillas grandes pueden tener mayor capacidad para retener esta humedad en ambientes secos.

Palabras clave: Estrés hídrico, Polietilenglicol, Semillas, Zonas semi-aridas. 
Arid and semi-arid ecosystems in Mexico are highly degraded and fragmented because of land use change toward crop and livestock production (Montagnini et al. 2008). Continuous perturbation in semiarid ecosystems has generated loss of fertility and soil compaction, significantly reducing the capacity of ecosystems to recover from perturbation. Moreover, the scarcity of rainfall means that recovery of the structure and functioning of arid and semiarid ecosystems; i.e., their resilience, could take decades (Maestre 2003).

Water is the most limiting resource for germination and establishment in arid ecosystems (Noy-Meir 1973), and its availability may be strongly affected by climate change (Brown et al. 1997). By 2060, average annual temperature in Mexico have been predicted to have increased by $2.3{ }^{\circ} \mathrm{C}$ and annual rainfall to have decreased by $9 \%$ (SáenzRomero et al. 2010). In this context, it is a priority to select suitable species for restoration, considering not only current conditions, but also the response and anticipated adaptation to changes in rainfall patterns and the incidence of more intense droughts (Harris et al. 2006).

In arid ecosystems, many plant species can be expected to be drought-tolerant and capable of germinating under low water potentials. However, wide interspecific variation of these features have been reported (Metz et al. 2010, Merino-Martín et al. 2017). Sensitivity to drought conditions depends on multiple factors and may be higher during germination and establishment (Fischer \& Turner 1978). During germination, more tolerant plants have an advantage because they can establish in zones where others cannot (Leishman \& Westoby 1994, Radhouane 2007). Identifying drought-tolerant plants in the earliest phase of development is an important consideration in the selection of species for conservation, management and restoration efforts (Cochrane et al. 2014).

Components of the life history of plants, such as seed size, are significantly associated with plant height, growth form and dispersal mode, and can also influence recruitment patterns (Leishman \& Westoby 1994). Seed size has a high impact on capacity and time of germination, establishment and survival of seedlings during early stages of the life cycle, when plants are more susceptible (Baskin \& Baskin 1998). In general, average germination time tends to be greater for larger-sized seeds (Norden et al. 2009), while small seeds absorb water faster than large seeds because of their larger surface-area-to-mass ratio (Kikuzawa \& Koyoma 1999).

Some studies have evaluated seed germination under drought conditions; however, the importance of seed size has received little attention in semiarid plants ( $\underline{\mathrm{De}}$ Villalobos \& Peláez 2001, De la Barrera \& Nobel 2003, Flores \& Briones 2001, Van den Berg \& Zeng 2006, Merino-Martín et al. 2017). In general, higher germination rates occur within a range of water potentials from 0 to -0.5 $\mathrm{MPa}$. The effect of seed size has been analyzed mainly in commercial species (Al-karaki 1998, Almansouri et al. 2001, Kaydan \& Yagmur 2008, Gholami et al. 2009). Recent studies with wild species reported the unequivocal role of seed size in germination in semi-arid environments. For example, Kidson \& Westoby (2000) argued that larger seeds are able to germinate better under drought, while Merino-Martín et al. (2017) reported that most light seeds had higher germination and emergence under dry conditions than heavier seeds. The authors recognize that more studies are required in order to understand whether the role of seed size in germination response under drought is general or species-specific.

We evaluated seed germination in seven shrub plants abundant in a semiarid scrub in central Mexico (GelvizGelvez \& Pavón 2013). These species have ecological attributes that make them suitable for potential use in ecological restoration: high frequency, considerable land cover and a high level of sociability (Gelviz-Gelvez et al. 2014). The latter attribute denotes the distribution pattern and ability of a species to associate with others rather than forming pure stands (Wittaker 2012). These characteristics can facilitate the establishment of species in advanced successional stages (Gelviz-Gelvez et al. 2014) and positive interaction with mycorrhizal fungi (Camargo-Ricalde et al. 2002, Montaño-Arias et al. 2008). On the other hand, several shrub plants appear not to decrease their potential distribution under conditions of climate change when evaluated by potential distribution modeling (Gelviz-Gelvez et al. 2014). Given the potential role of these species in restoration, it is important to test whether their seeds are tolerant to water stress and whether their seed size affects germination. We hypothesize that under drought conditions, small-seeded species will germinate more quickly and in higher proportions than large-seeded species, because the higher surface-area-to-volume ratio of their seeds enables more rapid and efficient water uptake. This study may help further our understanding of the recruitment of valuable species for restoration and may help select those most suitable for germination under different drought intensities.

\section{Materials and methods}

We selected seven shrub plants typical of semi-arid environments of central Mexico, and of ecological importance in these communities, given their high abundance and potential role in ecological restoration (coverage, density, frequency, and sociability, and the presence of mycorrhizal association), and because of their potential resilience to climate change conditions (GelvizGelvez et al. 2014). The species are Ageratina espinosarum (A. Gray) R. M. King \& H. Rob., Flourensia resinosa 
(Brandegee) S. F. Blake., Zucc., Montanoa tomentosa Cerv., Gymnosperma glutinosum (Spreng.) Less (Asteraceae), Dalea bicolor Humb. \& Bonpl. Ex Willd., Eysenhardtia polystachya (Ortega) Sarg., and Mimosa pringlei S. Watson (Fabaceae).

The sites where we collected the seeds of the all species, is in the semiarid shrubland of Central Mexico (19 $50^{\circ}$ $20^{\circ} 40^{\prime} \mathrm{N}$ and $\left.98^{\circ} 35^{\prime}-99^{\circ} 25^{\prime} \mathrm{W}\right)$. with an annual mean temperature between 15 and $19{ }^{\circ} \mathrm{C}$ and an annual precipitation of less of $450-700 \mathrm{~mm}$. for a more detailed description of the study sites see Gelviz-Gelvez \& Pavón (2013). The semiarid shrubland is characterized by Acacia farnesiana, Celtis pallida, Cordia boissieri, Dalea bicolor, Eysenhardtia polystachya, Forestiera angustifolia, Gymnosperma glutinosum, Karwinskia humboldtiana, Lantana involucrata and Montanoa tomentosa, among others (Gelviz-Gelvez \& Pavón 2013). Our field observations indicate that all seven species produce fruits between May and December; however, phenological data by species is not available in our study or in the literature. The only exception is E. polystachya, which bears fruit during November-December (Calderón-de Rzedowski \& Rzedowski 2005).

At each site about 500 ripe fruits were collected from at least 20 healthy individuals per species in natural populations in five localities of Hidalgo state, Mexico: Ixmiquilpan, Zimapán, Pachuca, Mextitlán and Tula, during July and September 2015. Seeds were removed from the fruits, selecting only those that presented no apparent damage, and were stored in paper bags in the dark until processed. The seeds were sterilized with $0.5 \%$ sodium hypochlorite for $5 \mathrm{~min}$., washed with deionized water and exposed to air until their surface was dry.

Mean seed size was obtained by weighing five subsamples of 100 seeds per species. Each subsample was weighed using an analytical balance (OHAUS Adventure model, USA) with $\pm 0.0001 \mathrm{~g}$ accuracy. We considered small seeds those weighing less than $500 \mathrm{mg}$. Five species had small seeds (seed size ranging from 30 to $187 \mathrm{mg}$ ); A. espinosarum $(30 \pm 6.97 \mathrm{mg})$, G. glutinosum (118.7 \pm $40.7 \mathrm{mg}), M$. tomentosa $(143 \pm 8.6 \mathrm{mg})$ and D. bicolor $(169.9 \pm 8.9 \mathrm{mg})$ and three species had large seeds (seed size ranging from 500 to $948 \mathrm{mg}$ ); F. resinosa (548 \pm $24.28 \mathrm{mg})$, and E. polystachya $(786 \pm 69.8 \mathrm{mg})$, and M. pringlei $(948 \pm 23.53 \mathrm{mg})$. Seed traits such as the shape or presence of dispersal structures could be important for germination. The seeds of $M$. tomentosa, A. espinosarum and G. glutinosum have elongated achenes (Rzedowski \& Calderón-de Rzedowski 1985). Seeds of Gymnosperma glutinosum have wind dispersal syndrome (Jurado \& Estrada 2001) and Ageratina spp. seeds have anemochory dispersal syndrome (Cortés-Flores et al. 2013). Seeds of Eysenhardtia polystachya (Jurado \& Estrada 2001),
Flourensia (Valencia-Díaz \& Montaña 2003), Mimosa spp. (Jurado \& Estrada 2001), Montanoa spp. and Dalea spp. (Cortés-Flores et al. 2013) have autochorous seeds.

We assessed germination of all species once the seeds had been collected and dried. Germination was carried out from September to November 2015. We used a pregermination treatment for species with low seed germination (M. pringlei and D. bicolor) by rubbing them against sandpaper to expose the embryo without damaging it, following the method of Flores \& Briones (2001). The other species received no pre-germination treatment. Seeds of the seven selected species were placed in Petri dishes with three layers of filter paper (Whatman No. 1) as a substrate for germination. The experiment consisted of control treatments $\left(T_{1}=0 \mathrm{MPa}\right)$ and four water potential treatments $\left(\mathrm{T}_{2}=-0.2 \mathrm{MPa}, \mathrm{T}_{3}=-0.4 \mathrm{MPa}, \mathrm{T}_{4}=-0.6 \mathrm{MPa}\right.$ and $\mathrm{T}_{5}=-0.8 \mathrm{MPa}$ ), which were obtained using polyethylene glycol (PEG 6000) with different water potentials. The concentrations used for the different water potential levels were determined based on Villela et al. (1991) . For each treatment, the PEG-6000 was diluted in $1 \mathrm{~L}$ of distilled water in the appropriate proportion and stirred for 16 hours. The amount of PEG-6000 used for the treatments was $119.5 \mathrm{~g}$ for $\mathrm{T}_{2}, 178.3 \mathrm{~g}$ for $\mathrm{T}_{3}, 223.6 \mathrm{~g}$ for $\mathrm{T}_{4}$, and $261.9 \mathrm{~g}$ for $\mathrm{T}_{5}$. Five replicates were conducted, with 20 seeds each, for a total of 100 seeds per species per treatment. Distilled water was used as the control, since this has the maximum water pressure value $(0 \mathrm{MPa})$. All seeds were placed within a plant growth chamber (VWR model 2015) at a temperature of $25 \pm 2{ }^{\circ} \mathrm{C}$ and $12 \mathrm{~h} \mathrm{light} / 12 \mathrm{~h}$ darkness. Germination was recorded daily for a period of one month, which is the recommended time for germination tests (Baskin \& Baskin 1998). We considered a seed to have germinated when the emerged radicle reached $\geq 2 \mathrm{~mm}$ in length (Iqbal et al. 2019).

After the month of evaluation, we calculated the germination proportion in each treatment. Once the experiment was completed, seeds that had not germinated were opened and observed under a stereomicroscope in order to evaluate the state of the endosperm and embryo (Ooi et al. 2004).

Data for the $-0.8 \mathrm{MPa}$ treatment were not modelled because the majority of species did not germinate, except E. polystachya of which a few seeds germinated. The relationship between seed size and seed germination under drought was evaluated using a generalized linear model (GLM) with binomial error, considering water potential as a factor with four levels, and mean seed size per species as the regressor variable. To determine in what treatment, the germination was significant in relation to seed size, we used the "ggscatter" function for Pearson's correlations, considering significance at $p=0.05$. All statistical analyses were conducted using R version 3.30 ( $\underline{\text { C Core Team 2016). }}$. 


\section{Results}

We tested viability by dissection and found that ungerminated seeds of all species were viable. Germination in the control treatment $\left(\mathrm{T}_{1}\right)$ was highest for all seven species and decreased water potential produced a decrease in germination in all of them. This general effect was detected for each particular species and was less gradual for two taxa, A. espinosarum and M. pringlei, which presented a large variation in germination proportion between the intermediate treatments $(-0.2,-0.4 \mathrm{MPa})$ (Figure 1). Germination proportion (bringing all the species together for each treatment) were different, indicating they differed in their sensitivity to drought (Figure 2). For example, E. polystachya was the least sensitive, having a $66 \%$ reduction in germination at $-0.6 \mathrm{MPa}$, while G. glutinosum, $M$. tomentosa, D. bicolor and $F$. resinosa had $100 \%$ reduction at the same water potential, thus being the most sensitive species to drought.

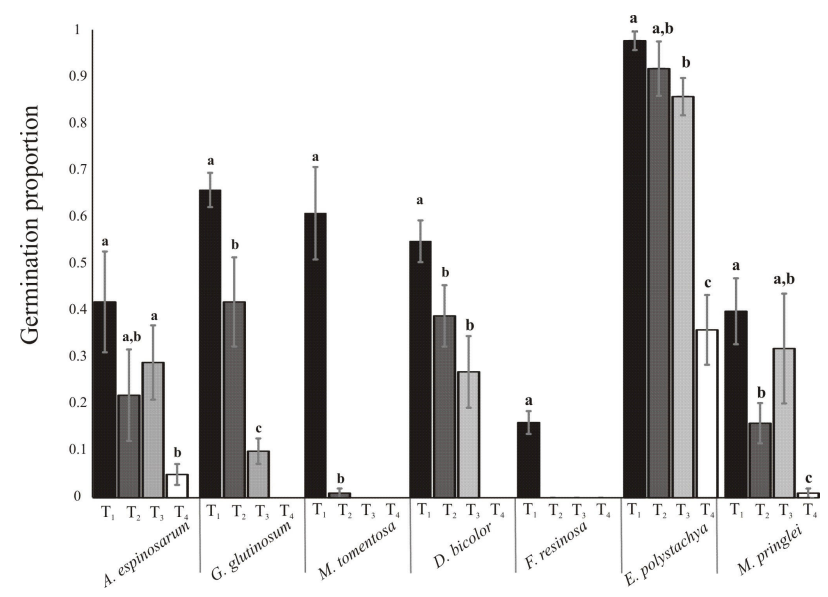

Figure 1. Mean germination proportion and standard error values of the seven shrub plants under four water potential treatments: $\mathrm{T}_{1}$ ) control, $\mathrm{T}_{2}$ ) seed germination at $-0.2 \mathrm{MPa}, \mathrm{T}_{3}$ ) seed germination at $-0.4 \mathrm{MPa}$, and $\mathrm{T}_{4}$ ) seed germination at $-0.6 \mathrm{MPa}$. Letters ( $\mathrm{a}, \mathrm{b}, \mathrm{c}$, d) denote significant differences.

Significant effects of water potential, seed size and their interaction were detected in the germination proportion (Table 1). For the control, seed size did not affect germination; however, under drought conditions, germination proportion increased with seed size and this effect became more pronounced with increased drought condition, as demonstrated by an increase in both the slope and significance of the relationships (Table 2, Figure 3). Overall, seed germination was driven much more strongly by water potential treatment than by seed size, with these two factors explaining 29 and $7 \%$ of the total variance respectively ( $\underline{\text { Table } 2}$ ).

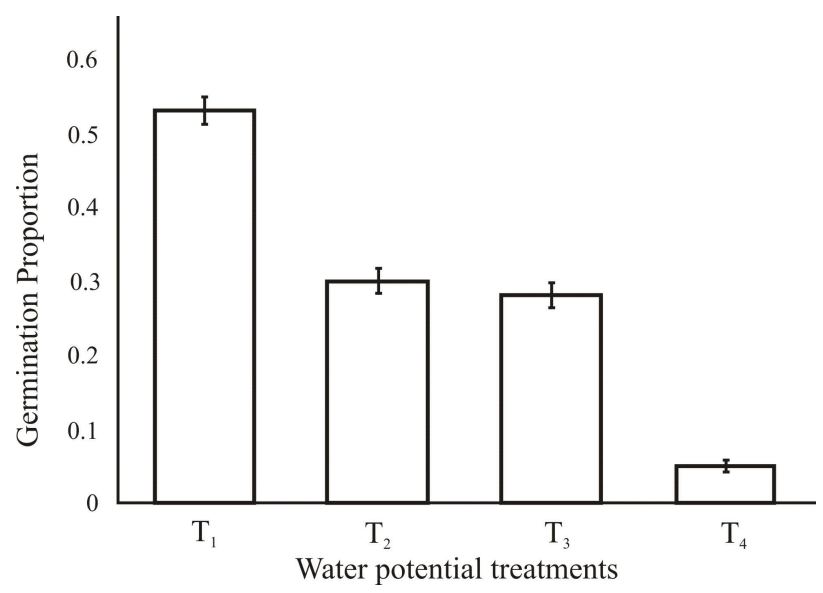

Figure 2. Mean germination proportion and standard error for all individuals that germinated by treatment. $\mathrm{T}_{1}$ ) control, $\mathrm{T}_{2}$ ) seed germination at $-0.2 \mathrm{MPa}, \mathrm{T}_{3}$ ) seed germination at $-0.4 \mathrm{MPa}$, and $\mathrm{T}_{4}$ ) seed germination at $-0.6 \mathrm{MPa}$.

\section{Discussion}

As expected, low water availability limited seed germination in semiarid plant species. However, some species were able to germinate at low water potentials: E. polystachya, A. espinosarum and $M$. pringlei had relatively high germination at -0.2 to $-0.6 \mathrm{MPa}$. These species could therefore be successful in environments with low water availability, as Briedé \& Mckell (1992) found in seven perennial arid land species subjected to moisture stress.

Our results do not support the hypothesis that smallseeded species germinate more than large-seeded species under drought conditions, as found by Merino-Martín et al. (2017). Our results showed under drought conditions, largeseeded species exhibited higher germination (E. polystachya and $M$. pringlei), in contrasts with small-seeded species.

Table 1. Coefficients for water potential treatments and interaction with seed size derived from the GLM binomial model. Water potential treatments: $\mathrm{T}_{2}=-0.2 \mathrm{MPa}, \mathrm{T}_{3}=-0.4 \mathrm{MPa}, \mathrm{T}_{4}=-0.6 \mathrm{MPa}$. The significance value was $<0.001$.

\begin{tabular}{|c|c|c|c|}
\hline & Estimate & $z$ value & $p$ \\
\hline Intercept & 0.1275 & 0.447 & 0.655 \\
\hline $\mathbf{T}_{2}$ & 0.838 & 1.964 & 0.051 \\
\hline $\mathbf{T}_{3}$ & 1.542 & 3.310 & $<0.001$ \\
\hline $\mathbf{T}_{4}$ & 4.24 & 3.808 & $<0.001$ \\
\hline Seed size $* \mathbf{T}_{2}$ & -0.011 & -0.135 & 0.892 \\
\hline Seed size $* \mathbf{T}_{3}$ & 0.130 & -1.482 & 0.140 \\
\hline Seed size $* \mathbf{T}_{4}$ & 0.2330 & -1.434 & 0.153 \\
\hline
\end{tabular}


Table 2. Paired comparisons of seed size effects on germination among water potential treatments for seven shrub plants. Water potential treatments: $\mathrm{T}_{1}=0 \mathrm{MPa}, \mathrm{T}_{2}=-0.2 \mathrm{MPa}, \mathrm{T}_{3}=-0.4 \mathrm{MPa}$, $\mathrm{T}_{4}=-0.6 \mathrm{MPa}$. The significance value was $<0.001$.

\begin{tabular}{llll}
\hline Contrast & Estimate & $\boldsymbol{z}$ value & $\boldsymbol{p}$ \\
\hline $\mathbf{T}_{2}-\mathbf{T}_{1}$ & -1.338 & -7.583 & $<0.001$ \\
$\mathbf{T}_{3}-\mathbf{T}_{1}$ & -1.806 & -9.647 & $<0.001$ \\
$\mathbf{T}_{4}-\mathbf{T}_{1}$ & -4.665 & -10.21 & $<0.001$ \\
$\mathbf{T}_{3}-\mathbf{T}_{2}$ & -0.468 & -2.358 & 0.076 \\
$\mathbf{T}_{4}-\mathbf{T}_{2}$ & -3.327 & -7.207 & $<0.001$ \\
$\mathbf{T}_{4}-\mathbf{T}_{3}$ & -2.859 & -6.137 & $<0.001$ \\
\hline
\end{tabular}

The rationale behind the proposed hypothesis was that under natural conditions, small seeds with a high surfacearea-to-volume ratio may imbibe water more quickly than large seeds with a lower ratio, particularly when periods of available soil moisture are short. However, when water potential is constantly low, higher dehydration of the seed tissues is expected in seeds with a higher surface-area-tovolume ratio, which could explain our results under conditions of constant dryness.

Other functional seed traits may have an effect on germination; e.g., coat structure, shape, the presence or absence of spines, presence of endosperm, dispersal structures, tubercles or the presence or absence of mucilage (Harper et al. 1970, Mott 1974, Valencia-Díaz et al. 2015). Bu et al. (2016), examining 383 Alpine meadow species, found a combined effect of shape and volume of seeds on germination, where the volume of the seed had an effect on the germination of elongated seeds. In addition, the hypothesis of Merino-Martín et al. (2017) that small-seeded species germinate more than large-seeded species under drought could be more relevant in round seeds. We believe that more experiments considering the process of water gain and loss in seeds under heterogeneous water conditions over time are required in order to further test the role of seed size in dry environments.

The seeds of two of the seven species studied have physical latency, and mechanical scarification was used to break the dormancy of the seeds. It was considered that E. polystachya and M. pringlei had physical latency because they have an impermeable layer that prevents seed germination when scarification treatment is not applied. The layers of impervious seeds in the fabaceae can be produced by the presence of a palisade layer (Rolston 1978, Bianco \& Kraus 2005), or by the presence of different substances such as cutaneous lignin, quinones, or insoluble suberine peptides that can reduce germination (Rolston 1978, Werker 1980, Valdovinos-Ponce et al. 1994, Sahai \& Pal 1995, Baskin \& Baskin 2014). Thus, seeds from all species were in the same condition to germinate under the water potential treatments. In addition, we found that the ungerminated seeds at the end of the experiment were viable.

Comparison of germination proportions among species can be valuable for the selection of species for restoration in the semiarid zones of central Mexico. An interesting case is that of E. polystachya, the species with the largest seed size, and the least affected by drought. It has a wide distribution that ranges from southeastern Arizona to southern Mexico. It is also found in different vegetation types, ranging from tropical forests to semiarid shrubland, with mean annual temperatures between 12 and $19{ }^{\circ} \mathrm{C}$ and mean annual precipitation between 300 and $1,800 \mathrm{~mm}$. In addition, projections for E. polystachya under a higher water stress scenario than current conditions show that this species would maintain its distribution area until 2050 (GelvizGelvez et al. 2014). Given this evidence, we consider E. polystachya to be an important species that is suitable for use in restoration in arid and semi-arid ecosystems of central Mexico.

On the other hand, even with its large seeds, F. resinosa did not respond in the same way, perhaps because some other morphological (development of the embryo) or physical (permeability of the seed coat) seed properties or physiological features that can produce dormant seed-stages and that were not measured in this study might have had a significant effect on its germination. Components of the life history of plants, including type of fruit, form of growth, color and dispersion form or agent, have been considered of great importance to find patterns of responses to environmental conditions (Cárdenas-Arévalo \& Vargas-Rios 2008). F. resinosa is distributed in zones with annual rainfall higher than $500 \mathrm{~mm}$ (Villaseñor 2016). Ford et al. 1983 finds that differences in the range of distribution of the species may influence germination proportion, favoring germination in species that are distributed over wide precipitation ranges. In the present study, E. polystachya has the widest distribution in this regard. Two species, A. espinosarum and $Z$. augusta, had higher germination at $0 \mathrm{MPa}$ than in the other treatments. Townend et al. (1996) reported that some species present a reduction in germination under water stress as a strategy to reduce the risk of death during the early stages of the seedling's life cycle. Moreover, these species can develop "opportunistic" or "cautious" evolutionary strategies in sites with high environmental variability (Gutterman 2000).

In our study we found that seed size affects germination in response to drought. Different authors have discovered that seed size can be easily correlated with other functional characteristics of plants (Venable \& Brown 1988, Khurana \& Singh 2000, Moles \& Westoby 2004, Merino-Martín et al. 2017) and even survival in later stages, with advantages for reproduction (Metz et al. 2010). For example, large seeds have the ability to store greater amounts of 


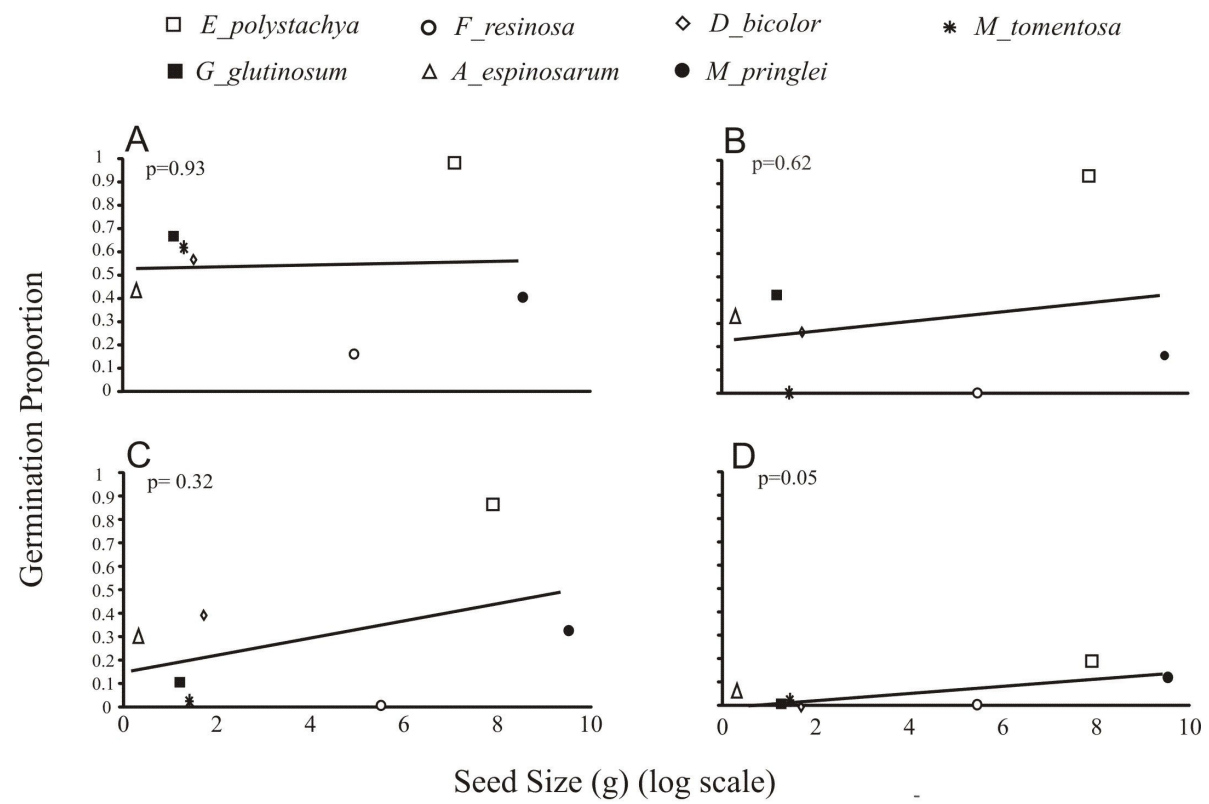

Figure 3. Correlation analysis of average seed size $(\mathrm{g})$ and germination proportion of seven shrub species, under four water potential treatments: A) control, B) seed germination at $-0.2 \mathrm{MPa}, \mathrm{C}$ ) seed germination at $-0.4 \mathrm{MPa}$, and D) seed germination at $-0.6 \mathrm{MPa}$. The line indicates the level of the slope in the correlation and $p$ indicates the significance level.

carbohydrate in their endosperm or cotyledons than do small seeds (Milberg \& Lamont 1997). This may enable early root or photosynthetic tissue development, producing a faster-growing plant (Hewitt 1998). Khurana \& Singh (2000) found that seedlings from large seeds survived extreme water stress, and have morphological and physiological mechanisms for tolerating very low soil moisture conditions over long periods that may be associated with the larger initial energy stock of the seedling.

In addition to the ecological characteristics previously evaluated, and considering the potential distribution under the most dramatic climate change scenarios (Gelviz-Gelvez et al. 2014), the use of species that germinate more readily under simulated drought for ecological restoration projects could reduce costs and increase establishment rates. However, more detailed studies of the germinated individuals during their early stages of development are required in order to determine whether there is a relationship between seed size and other attributes under different moisture conditions in both laboratory and field studies.

\section{Acknowledgments}

We would like to thank Dr. Arturo Sánchez Gonzalez for his valuable advice, Dr. Maritza Lopez Herrera for allowing us to use her laboratory facilities and providing advice that enriched this study and the anonymous reviewers who made observations that improved the manuscript. This study was supported by FOMIX-CONACYT-98122.

\section{Literature cited}

Al-karaki GN. 1998. Seed size and water potential effects on water uptake, germination and growth on lentil. Journal of Agronomy and Crop Science 181: 237-242. DOI: https:// doi.org/10.1111/j.1439-037X.1998.tb00423.x

Almansouri M, Kinet JM, Lutts S. 2001. Effect of salt and osmotic stresses on germination in durum wheat (Triticum durum Desf.). Plant and Soil 231: 243-254. DOI: https://doi.org/10.1023/A:1010378409663

Baskin CC, Baskin JM. 1998. Seeds: Ecology, Biogeography and Evolution of Dormancy and Germination. San Diego, California: Academic Press. ISBN-10: 0120802635

Baskin CC, Baskin JM. 2014. Seeds: Ecology, Biogeography and Evolution of Dormancy and Germination. Second Edition. Academic Press, San Diego, California. ISBN: 9780124166837

Bianco CA, Kraus TA. 2005. Desarrollo y estructura de la semilla y el fruto de Adesmia bicolor (Poir.). DC. (Fabaceae). Phyton 54:71-77

Briedé JW, Mckell CM. 1992. Germination of 7 perennial arid land species, subjected to soil moisture stress. Journal of Arid Environments 23: 263-270. DOI: https:// doi.org/10.1016/S0140-1963(18)30515-9

Brown JH, Valone TJ, Curtin, CG. 1997. Reorganization of an arid ecosystem in response to recent climate change. Proceedings of the National Academy of Science of the United States of America 94: 9729-9733. DOI: https:// doi.org/10.1073/pnas.94.18.9729 
Bu HY, Wang XJ, Zhou XH, Qi W, Liu K, Ge WJ, Xu DH, Zhang ST. 2016. The ecological and evolutionary significance of seed shape and volume for the germination of 383 species on the eastern Qinghai-Tibet plateau. Folia Geobotanica 51: 333-341. DOI: https:// doi.org/10.1007/s12224-016-9271-y

Calderón-de Rzedowski G, Rzedowski J. 2005. Flora fanerogámica del Valle de México. México, DF: Comisión Nacional para el Conocimiento y Uso de la Biodiversidad e Instituto de Ecología AC. ISBN: 978-607-7607-36-6

Camargo-Ricalde SL, Dhillion SS, Grether R. 2002. Community structure of endemic Mimosa species and environmental heterogeneity in semi-arid Mexican valley. Journal of Vegetation Science 13: 697-704. DOI: https://doi.org/10.1111/j.1654-1103.2002.tb02097.x

Cárdenas-Arévalo G, Vargas-Ríos O. 2008. Rasgos de historia de vida de especies en una comunidad vegetal alterada en un páramo húmedo (Parque Nacional Natural Chingaza). Caldasia 30: 245-264. DOI: https://doi.org/ 10.15446/caldasia

Cochrane JA, Hoyle GL, Yates CJ, Wood J, Nicotra AB. 2014. Evidence of population variation in drought tolerance during seed germination in four Banksia (Proteaceae) species from Western Australia. Australian Journal of Botany 62: 481-489. DOI: https://doi.org/ $\underline{10.1071 / \mathrm{BT} 14132}$

Cortés-Flores J, Andresen E, Cornejo-Tenorio G, IbarraManríquez G. 2013. Fruiting phenology of seed dispersal syndromes in a Mexican Neotropical temperate forest. Forest Ecology and Management 289: 445-454. DOI: https://doi.org/10.1016/j.foreco.2012.10.038

De la Barrera E, Nobel PS. 2003. Physiological ecology of seed germination for the columnar cactus Stenocereus queretaroensis. Journal of Arid Environments 53: 297-306. DOI: https://doi.org/10.1006/jare.2002.1050

De Villalobos AE, Peláez DV. 2001. Influences of temperature and water stress on germination and establishment of Prosopis caldenia Burk. Journal of Arid Environments 49: 321-328. DOI: https://doi.org/10.1006/ jare.2000.0782

Fischer RA, Turner NC. 1978. Plant productivity in the arid and semiarid zones. Annual Reviews of Plant Physiology 29: 277-317. DOI: https://doi.org/10.1146/annurev.pp.29. $\underline{060178.001425}$

Flores J, Briones O. 2001. Plant life-form and germination in a Mexican inter-tropical desert: Effects of soil water potential and temperature. Journal of Arid Environments 47: 485-497. DOI: https://doi.org/10.1006/jare.2000.0 $\underline{728}$

Ford RH, Sharik TL, Feret PP. 1983. Seed dispersal of the endangered Virginia round-leafed birch (Betula uber).
Forest Ecology and Management 6: 115-128. DOI: https://doi.org/10.1016/0378-1127(83)90016-6

Gelviz-Gelvez SM, Pavón N. 2013. Diversidad de especies arbustivas en una zona semiárida del centro de México. Revisa Chapingo Serie Ciencias Forestales y del Ambiente 19: 323-335. DOI: http://dx.doi.org/10.5154/ r.rchscfa.2012.08.049

Gelviz-Gelvez SM, Pavón N, Illoldi-Rangel P, BallesterosBarrera C. 2014. Ecological niche modeling under climate change to select shrubs for ecological restoration in central Mexico. Ecological Engineering 74: 302-309. DOI: https://doi.org/10.1016/j.ecoleng.2014.09.082

Gholami A, Sharafi S, Sharafi A, Ghasemi S. 2009. Germination of different seed size of pinto bean cultivars as affected by salinity and drought stress. Journal of Food, Agriculture \& Environment 72: 555-558. DOI: https://www.researchgate.net/publication/237313172

Gutterman Y. 2000. Environmental factors and survival strategies of annual plant species in the Negev Desert, Israel. Plant Species Biology 15: 113-225. DOI: https:// doi.org/10.1046/j.1442-1984.2000.00032.x

Harper JL, Lovell PH, Moore KG. 1970. The shapes and sizes of seeds. Annual Review of Ecology and Systematics 1: 327-356.

Harris JA, Hobbs RJ, Higgs E, Aronson J. 2006. Ecological restoration and global climate change. Restoration Ecology 14: 170-176. DOI: https://doi.org/10.1111/ j.1526-100X.2006.00136.X

Hewitt N. 1998. Seed size and shade tolerance: a comparative analysis of North American temperate trees. Oecologia 114: 432-440. DOI: https://doi.org/10.1007/ s004420050467

Iqbal N, Manalil S, Chauhan BS, Adkins SW. 2019. Germination Biology of Sesbania (Sesbania cannabina): An Emerging Weed in the Australian Cotton agroenvironment. Weed Science 67: 68-76. DOI: https:// doi.org/10.1017/wsc.2018.62

Jurado E, Estrada E, Mole s̀ A. 2001. Characterizing plant attributes with particular emphasis on seeds in Tamaulipan thornscrub in semi-arid Mexico. Journal of Arid Environments 48: 309-321. DOI: https://doi.org/ $\underline{10.1006 / j a r e .2000 .0762}$

Kaydan D, Yagmur M. 2008. Germination, seedling growth and relative water content of shoot in different seed sizes of triticale under osmotic stress of water and $\mathrm{NaCl}$. African Journal of Biotechnology 7: 2862-2868. DOI: https://doi.org/10.5897/AJB08.512

Khurana E, Singh JS. 2000. Influence of seed size on seedling growth of Albizia procera under different soil water levels. Annals of Botany 86: 1185-2000. DOI: https://doi.org/10.1006/anbo.2000.1288 
Kidson R, Westoby M. 2000. Seed mass and seedling dimensions in relation to seedling establishment. Oecologia 125: 11-17. DOI: https://doi.org/10.1007/PL $\underline{00008882}$

Kikuzawa K, Koyama H. 1999. Scaling of soil water absorption by seeds: an experiment using seed analogues. Seed Science Research 9: 171-178. DOI: https://doi.org/10.1017/S0960258599000197

Leishman MR, Westoby M. 1994. The role of seed size in seedling establishment in dry soil conditions experimental evidence from semi-arid species. Journal of Ecology 82: 249-258. DOI: https://doi.org/10.23 $\underline{07 / 2261293}$

Maestre GFT. 2003. La restauración de la cubierta vegetal en zonas semiáridas en función del patrón espacial de los factores bióticos y abióticos. Ecosistemas 12:1-4.

Merino-Martín L, Courtauld C, Commander L, Turner S, Lewandrowski W, Stevens J. 2017. Interactions between seed functional traits and burial depth regulate germination and seedling emergence under water stress in species from semi-arid environments. Journal of Arid Environments 147: 25-33. DOI: https://doi.org/10.1016/ j.jaridenv.2017.07.018

Metz J, Liancourt P, Kigel J, Harel D, Sternberg M, Tielbörger K. 2010. Plant survival in relation to seed size along environmental gradients: a long-term study from semi-arid and Mediterranean annual plant communities. Journal of Ecology 98: 697-704. DOI: https://doi.org/ 10.1111/J.1365-2745.2010.01652.x

Milberg P, Lamont BB. 1997. Seed/cotyledon size and nutrient content play a major role in early performance of species on nutrient-poor soil. New Physiology 137: 665-672. DOI: https://doi.org/10.1046/j.1469-8137.1997. $\underline{00870 . x}$

Moles AT, Westoby M. 2004. Seedling survival and seed size: a synthesis of the literature. Journal of Ecology 92: 372-383. DOI: https://doi.org/10.1111/j.0022-0477.2004. 00884.x

Montagnini F, Islas AS, Santana MRA. 2008. Participatory approaches to ecological restoration in Hidalgo, México. Bois et Forêts des Tropiques 295: 5-20.

Montaño-Arias NM, Camargo-Ricalde SL, García-Sánchez R, Monroy-Ata A. 2008. Micorrizas Arbusculares en Ecosistemas áridos y Semiáridos. México: Instituto Nacional de Ecología - Secretaría de Medio Ambiente y Recursos Naturales, Mundi-Prensa SA de CV, Universidad Autónoma Metropolitana Iztapalapa, Universidad Nacional Autónoma de México. ISBN-13: 978-9687462561

Mott JJ. 1974. Factors affecting seed germination in three annual species from an arid region of Western Australia. Journal of Ecology 62: 699-709. DOI: https://doi.org/ $\underline{10.2307 / 2258950}$
Norden N, Daws MI, Antoine C, Gonzalez MA, Garwood NC, Chave J. 2009. The relationship between seed mass and mean time to germination for 1037 tree species across five tropical forests. Functional Ecology 23: 203-210. DOI: https://doi.org/10.1111/j.1365-2435.200 8.01477.x

Noy-Meir I. 1973. Desert ecosystems: Environment and producers. Annual Review of Ecology and Systematics 4: 25-51. DOI: https://doi.org/10.1146/annurev.es.04.11017 $\underline{3.000325}$

Ooi M, Auld T, Whelan RJ. 2004. Comparison of the cut and tetrazolium tests for assessing seed viability: a study using Australian native Leucopogon species. Ecological Management \& Restoration 5: 141-143. DOI: https:// doi.org/10.1111/j.1442-8903.2004.201-6.x

Radhouane L. 2007. Response of Tunisian autochthonous pearl millet (Pennisetum glaucum (L.) R. Br.) to drought stress induced by polyethylene glycol (PEG) 6000. African Journal of Biotechnology 6: 1102-1105.

R Core Team. 2016. R: A language and environment for statistical computing. $\mathrm{R}$ Foundation for Statistical Computing, Vienna, Austria. https://www.R-project.o $\underline{\mathrm{rg} /}$

Rolston MP. 1978. Water impermeable seed dormancy. The Botanical Review 44: 365-396. DOI: http://dx.doi.org/ 10.1007/BF02957854

Rzedowski J, Calderón de Rzedowski G. 1985. Flora fanerogámica del Valle de México (No. JRZ-1). México: Instituto de Ecología.

Sáenz-Romero C, Rehfeldt GE, Crookston NL, Duval P, StAmant R, Beaulieu J, Richardson BA. 2010. Spline models of contemporary, 2030, 2060 and 2090 climates for Mexico and their use in understanding climate change impacts on the vegetation. Climatic Change 102: 595-623. DOI: https://doi.org/10.1007/s10584-009-97 $\underline{53-5}$

Sahai K, Pal A. 1995. Studies on seed treatments and histochemical characters on water barriers in seed coat of Leucaena glauca (L.) Benth. Journal of Phytological Research 8: 97-100.

Townend J, Mtakwa PW, Mullins CE, Simmonds LP. 1996. Soil physical factor limiting establishment of sorghum and cowpea in two contrasting soil types in the semi-arid tropics. Soil and Tillage Research 40: 89-106. DOI: https://doi.org/10.1016/S0167-1987(96)80008-0

Valdovinos-Ponce G, Ponce-Salazar RM, Marquez-Guzman J. 1994. Histoquimica del desarrollo de la testa de Ipomoea aquatica (Convolvulaceae) en relación con la permeabilidad al agua. Phyton 55: 107-114.

Valencia-Díaz S, Flores-Morales A, Flores-Palacios A, Perea-Arango I. 2015. How does the presence of endosperm affect the seed size and germination? Botanical Science 93:783-789. DOI: https://doi.org/ $\underline{10.17129 / \text { botsci.251 }}$ 
Valencia-Díaz S, Montaña, C. 2003. Effects of seed age, germination substrate, gibberelic acid, light, and temperature on seed germination in Flourensia cernua (Asteraceae), a Chihuahuan Desert shrub. Southwestern Naturalist 48: 1-13. DOI: https://doi.org/10.1894/00384909(2003)048<0001:EOSAGS $>2.0$. CO;2

Van den Berg L, Zeng YJ. 2006. Response of South Africa indigenous grass species to drought stress induced by polyethylene glycol (PEG) 6000. South African Journal of Botany 72: 284-286. DOI: https://doi.org/10.1016/ j.sajb.2005.07.006

Venable DL, Brown JS. 1988. The selective interaction of dispersal, dormancy, and seed size as adaptation for reducing risk in variable environments. American Naturalist 131: 360-384.

Associated Editor: Alejandro Zavala Hurtado

Author contributions: SMGG conceived and designed the experiment and wrote the paper; NPP conceived the ideas, designed the methodology and reviewed the paper; JFR conceived the ideas, designed the methodology and reviewed the paper; FB analyzed the data and reviewed the paper; HP conceived the ideas, designed the methodology and reviewed the paper. All authors contributed critically to the drafts and have given their final approval for publication.
Villaseñor JL. 2016. Checklist of the native vascular plants on Mexico. Revista Mexicana de Biodiversidad 87: 559-902. DOI: https://doi.org/10.1016/j.rmb.2016.06.017

Villela FA, Doni-Filho L, Sequeira EL. 1991. Tabela de potencial osmótico em função da concentração de polietileno glicol 6.000 e da temperatura. Pesquisa Agropecuária Brasileira 26: 1957-1968.

Werker E. 1980. Seed dormancy as explained by the anatomy of embryo envelopes. Israel Journal of Plant Sciences 29: 22-44. DOI: https://doi.org/10.1080/00212 13X.1980.10676874

Wittaker RH. 2012. Classification of Plant Communities. Boston. London: Springer. ISBN-13: 978-94-009-9183-5 